\title{
Financial Analysis of Design 4 MW Mini-Hydro Power Plant In Cipelah, Bandung Regency
}

\author{
Dedy Setyo Oetomo ${ }^{1}$, Rizky Fajar Ramdhani ${ }^{2}$ \\ ${ }^{1}$ Wastukancana Technological College of Purwakarta, Indonesia \\ ${ }^{2}$ STT Wastukancana Purwakarta,Indonesia \\ Jl. Alternative Bukit Indah - Purwakarta, Mulyamekar, Kec. Babakancikao, Kabupaten Purwakarta, Jawa Barat 41151
}

\begin{abstract}
Mini Hydro Power Plants (PLTM) have low operating costs compared to Diesel Power Plants (PLTD). Mini hydro uses renewable energy from water resources.Planning the PLTMH in Cipelah District includes Weir, Intake, Soothing Tub (Forebay), Rapid Pipe ( Penstock), and selection of turbines. The power generated from the effective fall height is $71.3 \mathrm{~m}$, and a discharge of $2 \times 3.51 \mathrm{~m} 3 / \mathrm{s}$ is $4 \mathrm{MW}$. With a maximum capacity per year of 35.04 MWH. Total Production to PLN per year 23.93 MWH.The calculation of the feasibility analysis for the construction of a Mini Hydro Power Plant obtained an investment value of $6,297,758$ USD. The interest rate used is $6 \%$, the composition of the loan is 4,408,431 USD, and the equity is 1,889,328 USD. The IRR value of the PLTM CIpelah development plan is $20.58 \%$, and the NPV value is USD 11,952,550 and the Payback Period is five years. The conclusion is that the Cipelah PLTM construction project is feasible to build.
\end{abstract}

Keywords: PLTM, Total Energy Production, Investment Value, Feasibility Value.

\section{INTRODUCTION}

$\mathrm{O}$ ne of the energy sources is water resources. Water resources are a resource with various uses needed in everyday human life. The use of water also includes water to supply electrical energy, which is also a significant need. Limited electrical power is one of the problems. Efforts are needed to solve the problem, not to cause a crisis that can have a more substantial impact.

It is generally not economical to talk about the store and expand the network to remote areas regarding electricity supply. On the other hand, fossil fuel power plants for remote areas are usually not economical because the scale of the generation is too small. The cost of fuel is high. However, Electricity's provision must still carry out because it is an inevitable social investment in improving people's welfare.Installation of hydroelectric power plants or Microhydro Power Plants (PLTMH), especially in remote areas, still needs to be developed, seeing regions of Indonesia where much water has not to use optimally. There are stillmany remote areas in Indonesia that are not yet reaching by Electricity (PLN). Therefore, to meet the need for electric lighting in remote areas, creating a tool that can make hidden places cheap and environmentally friendly, namely the Microhydro Power Plant (PLTM). As an alternative to power plants, diesel (PLTD) which uses fuel oil, especially diesel, has higher operational costs than hydroelectric power plants
(Mini Hydro Power Plant) PLTM is also environmentally friendly.

The government has also made laws and regulations that support investment in the PLTM sector, namely: Government Regulation No. 03 of 2005 concerning Electricity states that availability of primary energy for power generation, the use of local energy sources are the priority with the obligation to prioritize the use of renewable energy sources.The minihydropower plant with the plan to be built is in Cipelah Village, Rancabali District, Bandung Regency. The water source used as input for the power plant is the Cibuni River, where the mainstay discharge from the Cibuni river reaches $8.83 \mathrm{M} 3$ / second.

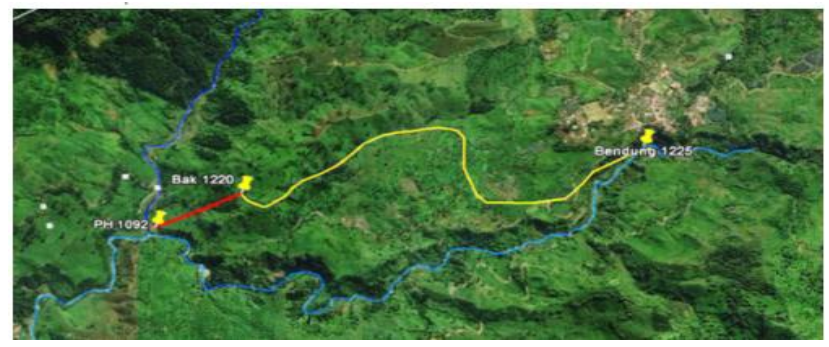

Figure.1. Power plant location map

Electricity production from this mini-hydropower plant will later sell to PLN, with the total output sold to PLN per year of 23,930.56 MWH. Suppose it assumes that the production escalation is $80 \%$ of the total. In that case, the average electricity production sold to PLN is around 19,144,448 $\mathrm{kWh}$ per year.

\section{METHODE AND FORMULA}

The project is a series of activities to manage resources with a planned time and cost to benefit. Therefore, we need to evaluate whether it considers the time, prices, and uses before the project starts and after the task runs.

Because of the limitation of resources, choices make among the alternative competing uses and investments. Regarding how countries allocate their scarce resources, the organization has distinguished two chief social types with a planned economic system. An organization with a free-market financial system, however, no country in the real world is either entirely centrally planned or operates a completely pure free-market system. It can say that no economic system can 
work without any state intervention or/and some production activities undertake by the state. Yet even in the US, the command principle has some sway. That is why, like almost all developing countries, the national governments of the economies in transition must take a role in formulating and evaluating investment projects. Of course, the mix of private and public sector investment varies from country to country. Either direct investment in the public sector or imposing controls on private investment or domestic taxes, tariffs, subsidies, and the rationing of scarce resources, the government is generally in a position to guide the development and restructuring of the economy in the country $[1]^{1}$. Project analysis is a method to evaluate an investment proposal itself and making convenient and reasonable choices among alternatives conveniently and comprehensively[2] ${ }^{2}$. A good investment project must include mainly costs and benefits of the investment and some other features of a proposal such as analysis related to input and output markets, location of the production unit, capacity, and technology. On the other hand, projects must analyze and evaluate to obtain some common yardstick, make decisions about realization and financing, and choose among alternative project proposals and their ranking. We can put into four categories the way of analysis and evaluation of a particular investment project from the different viewpoints as follows [3] $]^{3}$.

$\begin{aligned} \text { i. } & \text { Technical evaluation } \\ \text { ii. } & \text { Financial analysis } \\ \text { iii. } & \begin{array}{l}\text { Economic analysis iv. Risk, uncertainty, and } \\ \text { sensitivity analysis }\end{array}\end{aligned}$

In this article, particular importance has been given on the financial analysis while providing a brief explanation about others, at least what their means are

The financial analysis deals primarily with earning considerations of a project $[4]^{4}$. It is concerned whether the project will secure the funds it will need and repay and whether it can be financially viable or profitable. Financial analysis is examining commercial or private profitability from the firm's economic viewpoint. Therefore, financial accounting is helpful to investors interested in financing and for entrepreneurs who own the project. In financial analysis, we will calculate some measures to determine the profitability and repayment capability of the projects. These measures are base on the estimated costs and benefits of the projects and socalled financial cost-benefit analysis.

Since an investment project is a proposal to be realized in a proposed future, the prices will discuss. Indeed, the rate of

\footnotetext{
${ }^{1}$ Daggupta, A. K. and D. W. Pearce, 1981, Cost-Benefit Analysis: Theory and Practice, The Macmillan Press Ltd. London 1981.p.163

${ }^{2}$ Squire, L., H. G. Van Der Tak, 1975, Economic Analysis of Projects, World Bank, the J. Hopkins University Press, $153 p$

${ }^{3}$ Prof. Dr. ErkanRehber, Financial Analysis of Investment Project, Reseachgate Publication, 1999.

${ }^{4}$ Gittinger, P., 1972, Economic Analysis of Agricultural Projects, the Johns Hopkins University Press, Baltimore, and London
}

inflation does not only affect the future cash flows but also affect the cost of capital, i.e., discounting rate

\section{Cost of capital}

We need an appropriate discount rate to discount cash flows using discounted measures and use it as a yardstick compared with the calculated estimates. We can put this rate directly or indirectly. If funds use in investment were borrowed, the interest rate on borrowed money would now operating as the cost of capital. When non-borrowed funds are using, the cost of the capital may be best measured in an indirect way using opportunity cost $[5]^{5}$. The opportunity cost to a firm defineshow the help would have earned its most profitable alternative use. Devoting funds to a specific project, an investor is giving up other alternatives. Even if the investor has only one choice, he can put his money in a savings account. In this case, the interest rate of the savings account would be the opportunity cost.

The "cost of capital" is a necessary benchmark in picking the fair allowed rate of return. The cost of capital is the expected rate of return in capital markets on alternative investments of equivalent risk. The cost of debt capital is relatively straightforward to assess, but determining the cost of equity capital is much harder[6]

\section{Cash flows and derivation of the cash flow table}

The generation of project cash flows is crucial for both project managers and project owners. During project implementation, the cash flow is vital for assessing working capital requirements since the difference between project expenditures and payments determines the necessary capital reserves. Furthermore, an accurate cash flow is required to conduct project cost-benefit analysis, determine project financing requirements, and perform earned value analysis $[7]^{7}$.

Discounted measures of the project worth are base upon the cash flow table, which consists of investment and operating costs as outflows, gross benefits as inflows, covering the whole economic life of the project

\footnotetext{
${ }^{5}$ Gruebele, J. W., and T. L. Frey, 1976, Evaluating Investment Decisions of Agribusiness Firms, University of Illinois, College of Agri. Circular 1127, Urbana Illinois, p.4

${ }^{6}$ BenteVilladsenMichaelJ.VilbertDanHarrisA.Lawrence Kolbe, Risk, and Return for Regulated Industries, Academic Press, Science Direct, 2017.

${ }^{7}$ John-Paris Pantouvakis, Project Cash Flow Analysis in the presence of uncertainty in activity Duration and Cost, International Journal of Project Management, April2012, DOI: 10.1016/j.ijproman.2011.08.005
} 
Tabel .1. Example of Cash Flow

\begin{tabular}{|c|c|c|c|c|c|c|c|}
\hline DESCRIPTION & & & $\begin{array}{c}\text { YEAR'S (-1.5) } \\
\text { USD } \\
\end{array}$ & $\begin{array}{l}\text { YEAR'S (-1) } \\
\text { USD } \\
\end{array}$ & $\begin{array}{l}\text { YEAR'S-1 } \\
\text { (USD) }\end{array}$ & $\begin{array}{l}\text { YEAR'S-2 } \\
\text { (USD) }\end{array}$ & $\begin{array}{c}\text { YEAR'S-3 } \\
\text { (USD) }\end{array}$ \\
\hline \multicolumn{8}{|l|}{ InFlow : } \\
\hline Loan & & & $7,818,322$ & & 0 & 0 & 0 \\
\hline Equity & & & $3,350,709$ & & 0 & 0 & 0 \\
\hline Net Income & & & & 0 & $1,160,417$ & $1,694,282$ & $2,283,811$ \\
\hline Depreciation & & & & 0 & 439,100 & 439,100 & 439,100 \\
\hline Total Inflow & & & $11,169,031$ & 0 & $1,599,517$ & $2,133,382$ & $2,722,911$ \\
\hline \multicolumn{8}{|l|}{ OutFlow: } \\
\hline & & & $25 \%$ & $72 \%$ & & & \\
\hline Investment & & & $2,792,258$ & $8,041,702$ & 0 & 0 & 0 \\
\hline Loan Repayment & 10 & Year & 111,690 & 643,336 & $1,272,396$ & $1,272,396$ & $1,272,396$ \\
\hline Total Outflow & & & $2,792,258$ & $8,041,702$ & $1,272,396$ & $1,272,396$ & $1,272,396$ \\
\hline Inflow - Outflow & & & & & 327,121 & 860,986 & $1,450,515$ \\
\hline $\begin{array}{c}\text { YEAR BEGINNING } \\
\text { CASH }\end{array}$ & & & & & 0 & 327,121 & $1,188,108$ \\
\hline YEAR ENDING CASH & & & & & 327,121 & $1,188,108$ & $2,638,623$ \\
\hline
\end{tabular}

\section{Net Present Value}

Net present value (NPV) is the most straightforward discounted cash flow measure of a project. NPV is simply the total current value of the project's net cash flows computed by discounting the net cash flows over its life with a given appropriate interest rate. The NPV formula calculates the Present Net Value (NPV) of a series of cash flows based on a specified discount rate. We can explain NPV in a recipe as follow :

$\mathrm{NPV}=\mathrm{F} /\left[(1+\mathrm{i})^{\wedge} \mathrm{n}\right]$

Where,

$\mathrm{PV}=$ Present Value

$\mathrm{F}=$ Future payment (cash flow)

$\mathrm{i}=$ Discount rate (or interest rate)

$\mathrm{n}=$ the number of periods in the future the cash flow is

\section{Internal Rate of Return}

A third common way of using discounted cash flows for measuring the worth of a project is the internal rate of return (IRR). It is a discount rate that makes the net present value of a project equal to zero. This discount rate gives various names; the "solution rate,""the yield," or "the marginal efficiency of investment" (Rehber 1998). Unfortunately, there is no formula for directly finding the internal rate of return. That is why we do not have an efficient system that will give us the correct answer on the first try.

We are forcing to resort to trial and error. It is one way of calculating net present value, using progressively higher interest rates until the net present worth becomes negative. Then we interpolate to arrive at the IRR. The interest rate (i) at that time is called the IRR
Figure.2. Formulation of IRR

\begin{tabular}{|c|c|}
\hline $\begin{array}{l}\mathrm{NPV}=0 \\
\sum_{t=0}^{n} \frac{B_{t}-C_{t}}{(1+1)^{t}}=0\end{array}$ & $\operatorname{IRR} \Leftarrow \begin{array}{l}>\mathrm{i} \text { layak } \\
=\mathrm{i} \text { impas } \\
<\mathrm{i} \text { tak layak }\end{array}$ \\
\hline
\end{tabular}

\section{Evaluation of Criteria for a Single Project}

For a single project, the net present value must be equal or more than zero for the acceptance of the project, i.e., NPV must be positive. According to its net current worth, if a project is acceptable according to its net present value, it can also be accepted in according. In the case of an alternative project are available, projects having an internal rate of return above the opportunity cost of capital can be acceptable. In addition, they could be rank in order of the value of the internal rate of return (The lowest one is termed the "cutoff rate"). But in mutually exclusive projects, direct comparison of IRR can lead to wrong investment choice. To avoid erroneous evaluations, you can either discount the difference in net cash flows from alternative projects or by using the NPV criterion.

\section{RESULT}

\section{Basic Assumptions}

To simulate the calculation of the financial feasibility of a Mini Hydro Power Plant, in this case, the CipelahMini Hydro Power Plant with a capacity of $4 \mathrm{MW}$ which includes two turbines, each $2 \times 2 \mathrm{MW}$, it is necessary to have basic assumptions that are contextual following the general investment parameters prevailing in Indonesia, that is :

1. The investment planning projection period is 15 years 
2. VAT at $10 \%$ and PPH at $25 \%$, The interest rate that using as the basis for calculating bank loan interest rates is $14 \%$

3. The Grace Period or the construction period of the CipelahMini Hydro Power Plant is assumed to be two years, so the PLTM will only operate in the 3rd year

4. The selling price of Electricity to PLN is 12 cents dollars at a rupiah exchange rate of Rp.14,000, so the selling price of Electricity to PLN reaches a cost of USD 0.12, - / KWH (up to 8 years) and USD 0.75, - / KWh

5. The amount of electric power sold to PLN from the CipelasMini Hydro Power Plant 2x 2 MW is an average of 23,939 MWH.

6. The investment scheme that applies is $30 \%$ is Owner Equity, and $70 \%$ is a Bank Loan, with a loan period of 8 years.

7. Cost of Land Acquisition Where the area of land acquired is $10 \mathrm{Ha}$, the land acquisition price is IDR $50,000 / \mathrm{M} 2$

8. Non-construction costs that are entering into the EPC cost calculation are $5 \%$ of the EPC value

9. Licensing Fees and Legal Compliances (0.9\%), Cost of Compiling FS, DED and EPC Compliances (2.7\%), $0.17 \%$ Test and Commissioning Fee, Financing Cost in the form of Bank Provision Fee of $1.2 \%$

\section{Electricity Production and Projection of Electricity Sales to PLN}

As a first step in calculating financial feasibility, what needs to be figuring is the volume of electrical power that is generating and sells to PLN, which is as follows:

Tabel .2. Production of Electricity and electric power sold to PLN

\begin{tabular}{|c|c|c|c|}
\hline \multirow{2}{*}{ No. Description } & \multirow{2}{*}{$\begin{array}{l}\text { Capacity } \\
\text { Turbine }\end{array}$} & \multicolumn{2}{|c|}{ Yearly Production (Mwh) } \\
\hline & & Turbine 1 & Turbine 2 \\
\hline \multicolumn{4}{|l|}{ I. Coefisien Faktor From Water Production } \\
\hline 1 Max Production Capacity & & $17,520.00$ & $17,520.00$ \\
\hline 2 Yearly Production & & $17,204.97$ & $9,533.08$ \\
\hline \multicolumn{2}{|c|}{ Coefisien Factor (CF) } & \multicolumn{2}{|c|}{$76 \%$} \\
\hline \multicolumn{4}{|l|}{ II. Coefisien Faktor Plant } \\
\hline 1 Max Production Capacity & $2 \times 2 \mathrm{MW}$ & $17,520.00$ & $17,520.00$ \\
\hline \multicolumn{4}{|l|}{2 Energy Reduction (Assumsi) } \\
\hline - Availability Factor PLN (95\%) & & 860.25 & 476.65 \\
\hline - Maintenance (5\%) & & 860.25 & 476.65 \\
\hline - Own Uses $40 \mathrm{Kw}(0,5 \%)$ & & 86.02 & 47.67 \\
\hline 3 Production to PLN & & $15,398.45$ & $8,532.11$ \\
\hline 4 Total Production For PLN Annualy & & & $23,930.56$ \\
\hline \multicolumn{2}{|c|}{ Coefisien Factor (CF) } & \multicolumn{2}{|c|}{$68 \%$} \\
\hline
\end{tabular}

Source: Author analysis
Next, calculate the projected calculation of electricity sales to PLN for 20 years, where the price scheme follows the direction of the price set by PLN as the primary user of Electricity produced, as in the following table:

Tabel .3. Projection of Electricity Sales for 20 Years

\begin{tabular}{|c|c|c|c|c|c|c|c|c|c|c|}
\hline & $T H-1 \mid R p]$ & $T H-2(P p)$ & TH. $-\partial\left(\mathrm{PP}_{\mathrm{P}}\right.$ & TH. 4 (P) & TTH. 5 ( $\mathrm{Rp})$ & TH. 6 (Pp) & $\mathbb{T H} \cdot 7(\mathrm{RP})$ & TH. 8 (Pp) & TH. 9 9Pp] & TH-10(PD) \\
\hline & $0.0 \%$ & $00 \%$ & $100 \%$ & $100 \%$ & $100 \%$ & $10 \mathrm{~h}$ & 1 政 & $10 \%$ & $10 \%$ & $100 \%$ \\
\hline 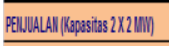 & 0 & 0 & 2.90059 & $2,900,59$ & $2,990,59$ & 23900559 & 23990,59 & 2390,59 & 2990055 & 2990,59 \\
\hline 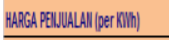 & 0 & 0 & 1,600 & 1,800 & 1800 & 1,800 & 1000 & 1,000 & 1,200 & 1,000 \\
\hline IILAPESUUALAI (Rp) & 1 & 0 & $402023,398,851$ & $402023,398,851$ & 402023,398985 & 402023398851 4 & 40203398814 & 420203988614 & $40203398981 \quad 40$ & 40203398981 \\
\hline & TH. 11 ( $\left.\mathrm{P}_{\mathrm{p}}\right)$ & $T H-12\left(P_{p}\right)$ & Th-18/Pp) & TH. $14\left(\mathrm{PP}_{\mathrm{P}}\right.$ & TH.15(5) & Th. $16(\mathrm{PP})$ & $\mathbb{H} \cdot 17\left(\mathrm{Ap}_{\mathrm{p}}\right.$ & TH.18(PQ) & TH-19(Pp) & ) TH.2OPp \\
\hline & $106 \mathrm{~h}$ & 1006 & $10 \% \mathrm{~h}$ & 1008 & $100 \%$ & $100 \%$ & $100 \%$ & 108 & 1008 & $10 \%$ \\
\hline 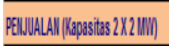 & 2900559 & 23900559 & 2900,59 & 29900.59 & $20,90,59$ & $29,90,590$ & 2990,59 & 2390,59 & 23,900550 & 239005059 \\
\hline 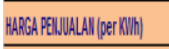 & 1,080 & 1,000 & 1,000 & 1,000 & 1,000 & 1,000 & 1,000 & 1,000 & 1,00 & 1,000 \\
\hline IIAPEDUNALAI (Pp) & $26,12,060,107$ & $25,127,087,407$ & $25,12,087,07$ & $20,12,087,407$ & $25,12,08,407$ & $261,27,087,407$ & $25,12,087,47$ & \begin{tabular}{|l|l|}
$25,12,087,07$ \\
\end{tabular} & \begin{tabular}{|l|l|}
7 & $2,12,087,077$
\end{tabular} & $25,127,07,100$ \\
\hline
\end{tabular}

Source: Author analysis

Civil Construction Costs and Mechanical and Electrical Costs Calculation of Civil Construction costs and Mechanical and Electrical Costs are the main things that calculated to carry out a financial feasibility simulation, where the cost component includes the following details:

Tabel .4. The amount of civil and mechanical, and electrical construction costs for Cipelah Mini Hydro Power Plant

\begin{tabular}{|c|c|}
\hline CIVIL WORKS & $3,734,129$ \\
\hline \begin{tabular}{l|l|} 
1|PREPARATORY WORK \\
\end{tabular} & 24.496 \\
\hline 2 WER and INTAKE WORKS & 307,412 \\
\hline 3 MUD POOL WORK & 67,295 \\
\hline 5 WATERWAY WORKS & $1,851,731$ \\
\hline \begin{tabular}{l|l}
6 & SETTLING POOL WORKS \\
\end{tabular} & 206,640 \\
\hline \begin{tabular}{l|l|}
7 & PENSTOCK WORKS \\
\end{tabular} & 261,631 \\
\hline \begin{tabular}{l|l}
8 & POWER HOUSE WORKS \\
\end{tabular} & 802,464 \\
\hline \begin{tabular}{l|l} 
ACCESS ROAD WORK \\
\end{tabular} & 183,106 \\
\hline 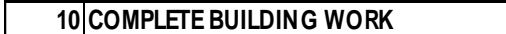 & 29,355 \\
\hline MECHANICAL, EIECTRICAL \& DISTRIBUTION & $1,765,129$ \\
\hline
\end{tabular}

Source: Author analysis

Land Acquisition Costs and Non-Construction Costs for CipelahMini Hydro Power Plant Development

Tabel .5. Land Acquisition Costs and Non-Construction Costs for Cipelah PLTM Development

\begin{tabular}{|r|l|lr|}
\hline No & \multicolumn{1}{|c|}{ DECRIPTIONS } & \multicolumn{2}{c|}{ COST } \\
\hline 1 & LAND AQUISTION & $\$$ & $357,142.86$ \\
\hline 2 & PERMIT AND LEGAL COMPLIANCES & $\$$ & $57,577.65$ \\
\hline 3 & FS, DED AND EPC COMPLIANCES & $\$$ & $172,732.95$ \\
\hline 4 & TEST AND COMISONING & $\$$ & $10,714.29$ \\
\hline 5 & BANK PPOVISON \& FINANCIAL APRANGEMENT & $\$$ & $81,286.09$ \\
\hline
\end{tabular}

Source: Author analysis

Total Budget Plan for CipelahMini Hydro Power Plant EPC 
Tabel .6. Comprehensive Budget Plan for CipelahMini Hydro Power Plant Development

\begin{tabular}{|c|c|}
\hline Work Descriptions & $\begin{array}{l}\text { Amout of Cost } \\
\text { (USD.) }\end{array}$ \\
\hline B & D \\
\hline LAND AQUISITION & 357,143 \\
\hline PERMIT AND LEGAL COMPLIANCES & 57,578 \\
\hline FS, DED AND EPC COMPLANCES & 172,733 \\
\hline TEST AND COMISIONING & 10,714 \\
\hline COST OF CAPITAL (BANK PROVISION \& FNANCIAL ARRANGEMENT & 81,286 \\
\hline CIVIL WORKS & $3,734,129$ \\
\hline 1|PREPARATORY WORK & 24,496 \\
\hline 2 WER and INTAKE WORKS & 307,412 \\
\hline 3 MUD POOL WORK & 67,295 \\
\hline 5 WATERWAY WORKS & $1,851,731$ \\
\hline 6 SETTUNG POOL WORKS & 206,640 \\
\hline 7 PENSTOCK WORKS & 261,631 \\
\hline 8 POWER HOUSE WORKS & 802,464 \\
\hline 9 ACCESS ROAD WORK & 183,106 \\
\hline 10 COMPLETE BUILDING WORK & 29,355 \\
\hline MECHANICAL, EEECTRICAL \& DISTRIBUTION & $1,765,129$ \\
\hline VAT $(10 \%)$ & 441,358 \\
\hline TOTAL & 5297758 \\
\hline
\end{tabular}

Source: Author analysis

\section{Operational Cost of PLTM Cipelah}

After knowing the number of investment costs for the construction of the Cipelah Mini Hydro Power Plant, the next step is to calculate the estimated operational costs of the PLTM operational activities if they are finished in building and after that, for more details, see the following table:

Tabel .7. Details of the operational costs of the CipelahMini Hydro Power Plant

\begin{tabular}{|c|c|c|c|c|c|}
\hline NO & DESCRIPTION & UNIT & $\mathrm{VOL}$ & UNIT COST & VALUE \\
\hline \multirow[t]{6}{*}{1} & Technical \& Administration & & & & $624,000,000$ \\
\hline & a Chief Operator & $\mathbf{R} \boldsymbol{p} / \mathrm{Thn}$ & 1.0 & $5,500,000$ & $71,500,000$ \\
\hline & Operator & Re $/$ Thn & 3.0 & $4,500,000$ & $175,500,000$ \\
\hline & c Techrician & Rq $/$ Thn & 4.0 & $3,500,000$ & $182,000,000$ \\
\hline & Administration & $\mathrm{PQ} / \mathrm{Thn}$ & 3.0 & $2,500,000$ & $97,500,000$ \\
\hline & e Security & $\mathbf{P Q} / \mathrm{Thn}$ & 3.0 & $2,500,000$ & $97,500,000$ \\
\hline \multirow[t]{2}{*}{2} & Management & & & & $455,000,000$ \\
\hline & a Direktur & Rp/Thn & 1.0 & $15,000,000$ & $195,000,000$ \\
\hline & & & & & \\
\hline 3 & Maintenance & $\mathrm{Rp} / \mathrm{Thn}$ & & $1,017,014,014$ & $1,017,014,014$ \\
\hline 4 & Insurance & $\mathrm{Rp} / \mathrm{Thn}$ & 1 & $75,000,000$ & $75,000,000$ \\
\hline
\end{tabular}

Loan Repayment Scheme from the CipelahMini Hydro Power Plant Development

Based on the assumptions previously mentioned, the return on investment scheme base on the investment value, which includes $70 \%$ of the total costs incurred. It bears an interest fee of $14 \%$, with a repayment period of the loan is 15 years.

Tabel .8. Investment Return Scheme Table

\begin{tabular}{|c|r|r|r|r|}
\hline \multicolumn{5}{|c|}{$\begin{array}{l}\text { INVESTATION PAYMENT SCHEME'S } \\
\text { PLTM 2X 2 MW }\end{array}$} \\
\hline \multicolumn{7}{|c|}{ U0\% Loans from Banking Sectors (Tenor 8 Years) } \\
\hline YEARS & \multicolumn{1}{|c|}{ LOANS } & INTEREST & LOAN INSTALLMENT & TOTAL PAYMENTS \\
\hline 0 & $4,408,431$ & - & - & - \\
\hline 1 & $3,963,021$ & 264,506 & 445,410 & 709,916 \\
\hline 2 & $3,490,886$ & 237,781 & 472,135 & 709,916 \\
\hline 3 & $2,990,424$ & 209,453 & 500,463 & 709,916 \\
\hline 4 & $2,459,933$ & 179,425 & 530,490 & 709,916 \\
\hline 5 & $1,897,613$ & 147,596 & 562,320 & 709,916 \\
\hline 6 & $1,301,554$ & 113,857 & 596,059 & 709,916 \\
\hline 7 & 669,732 & 78,093 & 631,823 & 709,916 \\
\hline 8 & 0 & 40,184 & 669,732 & 709,916 \\
\hline 9 & 0 & 0 & & \\
\hline 10 & 0 & 0 & & \\
\hline 11 & 0 & 0 & & \\
\hline 12 & 0 & 0 & & \\
\hline 13 & 0 & 0 & & \\
\hline 14 & 0 & 0 & & \\
\hline 15 & 0 & 0 & & \\
\hline
\end{tabular}

Source: Author analysis

Projected Profit and Loss Report on the Construction of the CipelahMini Hydro Power Plant

Tabel .9. Projected Profit and Loss Report on the Construction of the CipelahMini Hydro Power Plant

\begin{tabular}{|c|c|c|c|c|c|c|c|c|c|c|c|c|c|c|c|c|}
\hline \multicolumn{17}{|c|}{$\begin{array}{l}\text { PROJECTION OF INCOME STATEMENT PLTM CIPELAH } 2 \text { X } 2 \text { MW } \\
\text { ESTIMATED VALUE } \\
\text { FOR SELLING PRICES USD 0.12.-/KWh }\end{array}$} \\
\hline \multirow[b]{2}{*}{ DESCRIPTIONS } & \multicolumn{16}{|c|}{ POWERPLANT OPERATIONAL COST } \\
\hline & $\begin{array}{l}\text { YEARS - } 0 \\
\text { (USD) }\end{array}$ & $\begin{array}{l}\text { YEARS - 1 } \\
\text { (USD) }\end{array}$ & $\begin{array}{l}\text { YEARS - 2 } \\
\text { (USD) }\end{array}$ & $\begin{array}{l}\text { YEARS - } 3 \\
\text { (USD) }\end{array}$ & $\begin{array}{l}\text { YEARS - } 4 \\
\text { (USD) }\end{array}$ & $\begin{array}{l}\text { YEARS - 5 } \\
\text { (USD) }\end{array}$ & \begin{tabular}{c|} 
YEARS - 6 \\
(USD)
\end{tabular} & $\begin{array}{l}\text { YEARS - } 7 \\
\text { (USD) }\end{array}$ & $\begin{array}{c}\text { YEARS - } 8 \\
\text { (USD) }\end{array}$ & $\begin{array}{l}\text { YEARS - } 9 \\
\text { (USD) }\end{array}$ & $\begin{array}{l}\text { YEARS - } 10 \\
\text { (USD) }\end{array}$ & $\begin{array}{l}\text { YEARS - } 11 \\
\text { (USD) }\end{array}$ & $\begin{array}{c}\text { YEARS - } 12 \\
\text { (USD) }\end{array}$ & $\begin{array}{c}\text { YEARS - } 13 \\
\text { (USD) }\end{array}$ & $\begin{array}{c}\text { YEARS - } 14 \\
\text { (USD) }\end{array}$ & $\begin{array}{c}\text { YEARS - } 15 \\
\text { (USD) }\end{array}$ \\
\hline & & & & & & & & & & & & & & & & \\
\hline & & & & & & & & & & & & & & & & \\
\hline ELECTRICITY SELLING VALUE & 0 & 0 & 0 & $2,297,334$ & $2,297,334$ & $2,297,334$ & $2,297,334$ & $2,297,334$ & $2,297,334$ & $2,297,334$ & $2,297,334$ & $1,435,834$ & $1,435,834$ & $1,435,834$ & $1,435,834$ & $1,435,834$ \\
\hline \multicolumn{17}{|l|}{ COST } \\
\hline \begin{tabular}{|l} 
- Technical \& Administration Cost \\
\end{tabular} & 0 & 0 & 0 & 44,571 & 46,800 & 49,140 & 51,597 & 54,177 & 56,886 & 59,730 & 62,716 & 65,852 & 69,145 & 72,602 & 76,232 & 80,044 \\
\hline - Management Cost & 0 & 0 & 0 & 32,500 & 34,125 & 35,831 & 37,623 & 39,504 & 41,479 & 43,553 & 45,731 & 48,017 & 50,418 & 52,939 & 55,586 & 58,365 \\
\hline - Building Maintenance Cost & 0 & 0 & 0 & 37,341 & 39,208 & 41,169 & 43,227 & 45,389 & 47,658 & 50,041 & 52,543 & 55,170 & 57,929 & 60,825 & 63,866 & 67,060 \\
\hline -M\&E and Electricity Distribution Ma & 0 & 0 & 0 & 8,827 & 9,269 & 9,732 & 10,219 & 10,729 & 11,266 & 11,829 & 12,421 & 13,042 & 13,694 & 14,379 & 15,097 & 15,852 \\
\hline - Cost of Insurance & 0 & 0 & 0 & 5,357 & 5,357 & 5,357 & 5,357 & 5,357 & 5,357 & 5,357 & 5,357 & 5,357 & 5,357 & 5,357 & 5,357 & 5,357 \\
\hline - Retributions & 0 & 0 & 0 & 239 & 239 & 239 & 239 & 239 & 239 & 239 & 239 & 239 & 239 & 239 & 239 & 239 \\
\hline - Payment of Bank loans Interest & 0 & 709,916 & 709,916 & 709,916 & 709,916 & 709,916 & 709,916 & 709,916 & 709,916 & 0 & 0 & 0 & 0 & 0 & 0 & 0 \\
\hline - Depresiation dan Amortisation & 0 & 0 & 0 & 617,871 & 617,871 & 617,871 & 617,871 & 617,871 & 617,871 & 617,871 & 617,871 & 617,871 & 617,871 & 617,871 & 617,871 & 617,871 \\
\hline \begin{tabular}{|l|} 
Total Cost \\
\end{tabular} & 0 & 709,916 & 709,916 & $1,456,623$ & $1,462,785$ & $1,469,255$ & $1,476,049$ & $1,483,182$ & $1,490,672$ & 788,621 & 796,878 & 805,549 & 814,653 & 824,212 & 834,250 & 844,789 \\
\hline EARNING BEFORE TAXES & 0 & $-709,916$ & $-709,916$ & 840,710 & 834,548 & 828,078 & 821,285 & 814,151 & 806,662 & $1,508,713$ & $1,500,455$ & 630,285 & 621,181 & 611,621 & 601,584 & 591,045 \\
\hline TAXES & & 0 & 0 & 210,178 & 208,637 & 207,020 & 205,321 & 203,538 & 201,665 & 377,178 & 375,114 & 157,571 & 155,295 & 152,905 & 150,396 & 147,761 \\
\hline \begin{tabular}{|l|l|} 
EBIT \\
\end{tabular} & & $-709,916$ & $-709,916$ & 630,533 & 625,911 & 621,059 & 615,964 & 610,614 & 604,996 & $1,131,535$ & $1,125,341$ & 472,713 & 465,885 & 458,716 & 451,188 & 443,284 \\
\hline
\end{tabular}

Source: Author analysis 
International Journal of Research and Scientific Innovation (IJRSI) |Volume VIII, Issue VI, June 2021|ISSN 2321-2705

The Investment Payback Period for the Construction of the CipelahMini Hydro Power Plant

Tabel .10. The Investment Payback Period for the Construction of the PLTM Cipelah

\begin{tabular}{|c|c|c|c|c|c|c|}
\hline & & ת & $\begin{array}{l}\text { LATION OF } \\
\text { PLTM }\end{array}$ & EAH $2 \times 2 \mathrm{MW}$ & AYBACR PE & \\
\hline YEARS- & & CASH OUT & $\begin{array}{r}\text { CASH I } \\
\end{array}$ & SD) & & KUMULATIF \\
\hline KUMULATIF & YEAR & (USD) & NET PROFIT & DEPRECIATION & NET CASH FLOW (USD) & NET CASH FLOW \\
\hline 0 & 0 & $6,297,758$ & 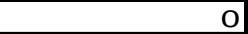 & 0 & $-6,297,758$ & $-6,297,758$ \\
\hline 1 & 1 & $\mathrm{O}$ & 0 & 0 & 0 & $-6,297,758$ \\
\hline 2 & 2 & 0 & 0 & 0 & 0 & $-6,297,758$ \\
\hline 3 & 3 & 0 & $1,458,582$ & 617,871 & $2,076,453$ & $-4,221,306$ \\
\hline 4 & 4 & o & $1,452,420$ & 617,871 & $2,070,291$ & $-2,151,015$ \\
\hline 5 & 5 & o & $1,445,949$ & 617,871 & $2,063,821$ & $-87,194$ \\
\hline 6 & 6 & $\mathrm{O}$ & $1,439,156$ & 617,871 & $2,057,027$ & $1,969,833$ \\
\hline 7 & 7 & $\mathrm{O}$ & $1,432,023$ & 617,871 & $2,049,894$ & $4,019,726$ \\
\hline 8 & 8 & o & $1,424,533$ & 617,871 & $2,042,404$ & $6,062,130$ \\
\hline 9 & 9 & o & $2,126,584$ & 617,871 & $2,744,455$ & $8,806,585$ \\
\hline 10 & 10 & $\mathrm{O}$ & $2,118,326$ & 617,871 & $2,736,197$ & $11,542,783$ \\
\hline 11 & 11 & o & $1,248,156$ & 617,871 & $1,866,027$ & $13,408,809$ \\
\hline 12 & 12 & 0 & $1,239,052$ & 617,871 & $1,856,923$ & $15,265,732$ \\
\hline 13 & 13 & o & $1,229,492$ & 0 & $1,229,492$ & $16,495,224$ \\
\hline 14 & 14 & 0 & $1,219,455$ & 0 & $1,219,455$ & $17,714,680$ \\
\hline 15 & 15 & 0 & $1,208,916$ & 0 & $1,208,916$ & $18,923,596$ \\
\hline
\end{tabular}

Pay Back

Periode

5 YEARS 1 MONTH

Source: Author analysis

Value of Financial Feasibility (IRR and NPV) of CipelahMini Hydro Power Plant Development

Tabel .11. Value of Financial Feasibility (IRR and NPV)

\begin{tabular}{|c|c|c|c|c|c|c|}
\hline \multicolumn{7}{|c|}{$\begin{array}{l}\text { TABLE CALCULATION OF IRR \& NPV } \\
\text { PLTM CIPELAH } 2 \times 2 \mathrm{MW}\end{array}$} \\
\hline \multirow{2}{*}{$\begin{array}{l}\text { YEA } \\
\mathbf{R}\end{array}$} & \multirow{2}{*}{ CASH OUT (USD) } & \multicolumn{2}{|c|}{ CASH IN (USD) } & \multirow{2}{*}{ ET CASH FLOW (USI } & \multicolumn{2}{|c|}{ DISCOUNTED CASH FLOW (USD) } \\
\hline & & NET PROFIT & DEPRECIATION & & $19 \%$ & $21 \%$ \\
\hline 1 & 0 & 0 & 0 & 0 & 0 & 0 \\
\hline 2 & 0 & 0 & 0 & 0 & 0 & 0 \\
\hline 3 & 0 & $1,458,582$ & 617,871 & $2,076,453$ & $1,232,200$ & $1,172,103$ \\
\hline 6 & 0 & $1,439,156$ & 617,871 & $2,057,027$ & 724,366 & 655,432 \\
\hline 7 & 0 & $1,432,023$ & 617,871 & $2,049,894$ & 606,600 & 539,801 \\
\hline 8 & 0 & $1,424,533$ & 617,871 & $2,042,404$ & 507,886 & 444,487 \\
\hline 9 & 0 & $2,126,584$ & 617,871 & $2,744,455$ & 573,500 & 493,614 \\
\hline 10 & 0 & $2,118,326$ & 617,871 & $2,736,197$ & 480,483 & 406,718 \\
\hline 11 & 0 & $1,248,156$ & 617,871 & $1,866,027$ & 275,360 & 229,234 \\
\hline 12 & 0 & $1,239,052$ & 617,871 & $1,856,923$ & 230,266 & 188,525 \\
\hline
\end{tabular}

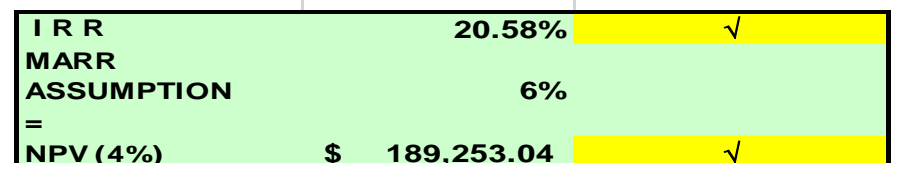

Source: Author analysis 
Tabel .12. Resume Financial Feasibility Analysis

\begin{tabular}{|l|rr|}
\hline ELECTRICITY SELLING PRICES & \multicolumn{2}{|c|}{ USD 0.12,-/KWH } \\
\hline Investations Value & USD & $6,297,758$ \\
\hline Loans & USD & $4,408,431$ \\
\hline Owner Equity & USD & $1,889,328$ \\
\hline Depresiation \& Amortisation & USD & 617,871 \\
\hline Bank Interest Value & $15.00 \%$ \\
\hline IRR & & $20.58 \%$ \\
\hline NPV & USD & 189,253 \\
\hline PBP Duration & & 5 Years, 1 month \\
\hline Derisinns & \multicolumn{2}{|c|}{ FINANCIAIIY FFASIRIF }
\end{tabular}

\section{CONCLUSION}

1. The conclusions of the research related to the Financial Analysis for the Development of the Cipelah Mini Hydro Power Plant are as follows:

2. The Cipelah PLTM can continue with a financial feasibility level in the form of an IRR of $20.58 \%$ and an NPV of USD 189,253. Also,a Payback period of investment is only five years.
3. The most significant cost component of PLTM Cipelah construction is the Civil and Mechanical Electrical costs, which reached USD 5,499,257.

4. Depreciation and Amortization Value of buildings and equipment and engineering and procurement activities are USD 617,871.

5. The annual operational cost of the PLTM Cipelah operation plan is USD 122,811.

6. The Loan-Equity composition applied in this study has been able to produce a feasible financial feasibility calculation

\section{REFERENCES}

[1] Dasgupta, A. K. and D. W. Pearce, 1981, Cost-Benefit Analysis: Theory and Practice, The Macmillan Press Ltd. London 1981.p.163.

[2] Frey, T. L., 1976, Time Value of Money and Investment Analysis; Explanation with Application to Agriculture. Dept. of Agri. Econ. University of Illinois, AET. 15-76.p.1

[3] Gittinger, P., 1972, Economic Analysis of Agricultural Projects, the Johns Hopkins University Press, Baltimore, and London.

[4] Gruebele, J. W., and T. L. Frey, 1976, Evaluating Investment Decisions of Agribusiness Firms, University of Illinois, College of Agri.Circular 1127, Urbana Illinois, p.4.

[5] Prof. Dr.ErkanRehber, Financial Analysis of Investment Project, Reseachgate Publication, 1999.

[6] Squire, L., H. G. Van Der Tak, 1975, Economic Analysis of Projects, World Bank, the J. Hopkins University Press, 153 p

[7] John-Paris Pantouvakis,Project Cash Flow Analysis in the presence of uncertainty in activity Duration and Cost, International Journal of Project Management, April2012,DOI: 10.1016/j.ijproman.2011.08.005 